\title{
POLYPLOIDY: A FACTOR IN THE EVOLUTION OF DICERANDRA BENTH. (LABIATAE)
}

\author{
R. B. HUCK* \& H. L. CHAMBERS ${ }^{\dagger}$
}

\begin{abstract}
Chromosome counts are reported for the first time in Dicerandra Benth. (Labiatae), a genus endemic to the south-eastern United States. Representative taxa are tetraploid $(n=16)$ and hexaploid $(n=24)$. Diploids were not found. The systematic, phytogeographic and conservation implications of polyploidy in this genus are discussed. The monophyletic nature of the genus is upheld by the discovery that both sections have a presumed base number of $x=8$. Hexaploidy has apparently evolved independently in all branches of sect. Dicerandra, but not in sect. Lecontea.
\end{abstract}

Keywords. Chromosomes, Dicerandra, endemic, Labiatae, polyploidy.

\section{INTRODUCTION}

Dicerandra Benth., a genus endemic to the south-eastern United States (Huck, 1987; Huck et al., 1989), occurs within the Atlantic and Gulf Coastal Plain Floristic Province, a region noted for biodiversity and high endemism (Thorne, 1993). Dicerandra was placed by Bentham \& Hooker (1876) in the Melissinoid group with North American genera Micromeria Benth., Hedeoma Pers., Satureja L., Conradina A. Gray and Calamintha Mill. Nine species in Dicerandra are now recognized (Fig. 1) and many are rare, with conservation of these taxa, especially those in the Lake Wales Region of Florida, of great interest (Huck et al., 1989; Christman \& Judd, 1990; McCormick et al., 1993; Lewis \& Crawford, 1995; McDonald \& Hamrick, 1996). An on-going investigation of the phytogeographic pattern, as well as a review of the systematics of the genus, is being conducted by the first author in preparation for the treatment in the Flora of North America.

Chromosome studies are of value in Labiate systematics (Chambers, 1961; Gray, 1965; Chambers \& Chambers, 1971; Irving, 1976; Harley \& Brighton, 1977; Gill, 1981; Harley \& Heywood, 1992; Marrero, 1992; Chambers \& Hummer, 1994). The continuing discovery of small morphological discontinuities between Dicerandra populations suggested to the authors that an investigation of cytology may provide important clues to understanding relationships in the genus. Objectives of this preliminary study are to provide chromosome counts for representative taxa in Dicerandra, to interpret these results in light of the distinctive phytogeography of the group, and to discuss systematic and conservation implications.

* PO Box 110530, Florida Museum of Natural History, Gainesville, FL 32611, USA.

+ USDA-ARS National Clonal Germplasm Repository, Corvallis, OR 97333, USA. 


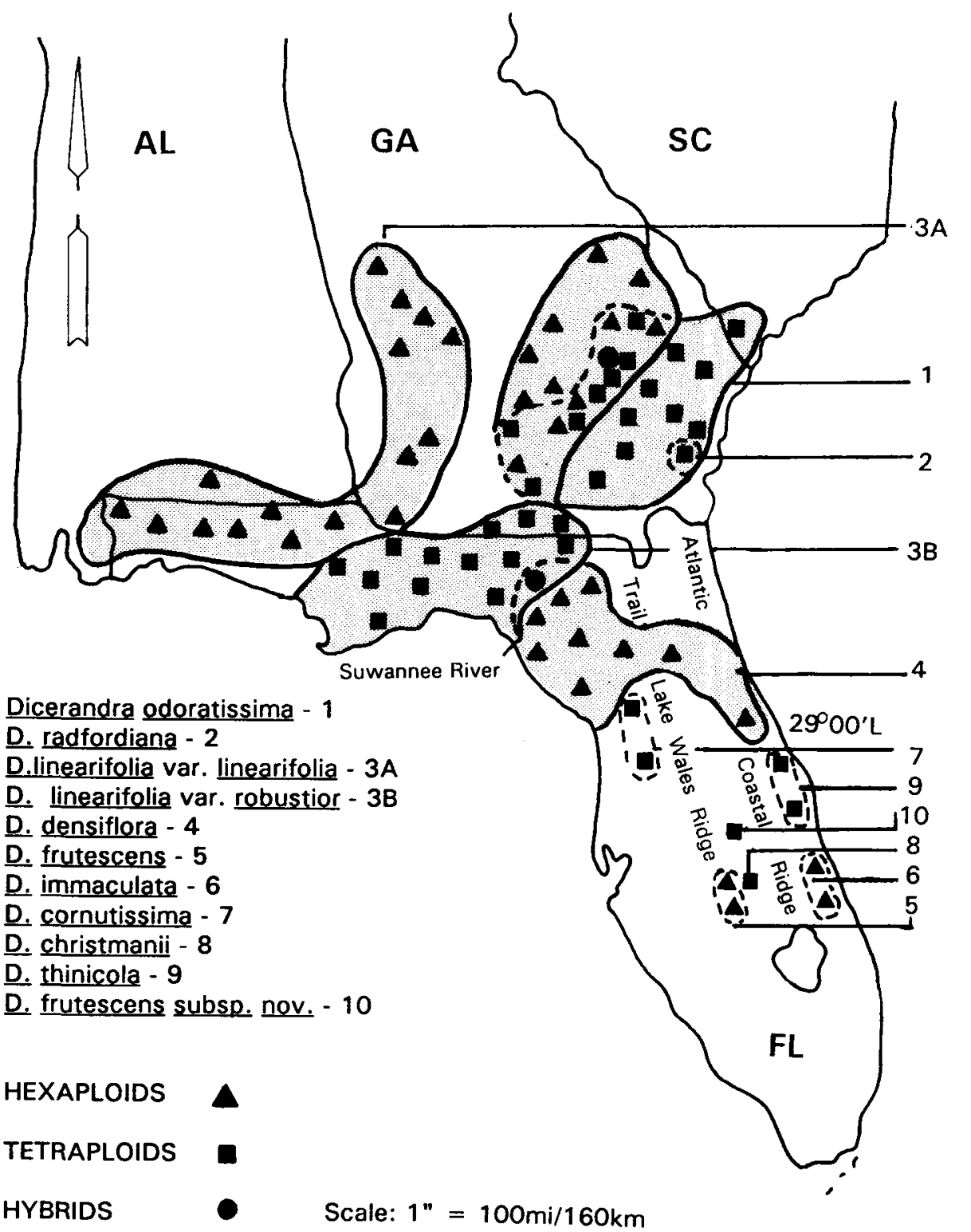

FIG. 1. South-eastern United States showing distribution of Dicerandra taxa, coincident with suspected hexaploid and tetraploid levels. Annuals are shaded.

\section{BIOLOGY OF THE GENUS}

The diagnostic character of Dicerandra is a spurred anther (Bentham, 1848). Members of the genus are obligate outcrossers (Huck, 1987), and, as with many other Labiatae, are pollinated by insects (Huck, 1992). Two sections within the 
genus have different pollination syndromes. Exclusive of the anthers, the floral morphology of each section is so distinct as almost to be considered in the informal super-groups of the Labiatae, Ocimoid-grex and Stachyoid-grex of Hedge (1992)! Section Lecontea has a tubular corolla, inserted stamens and style under the upper lip, and sect. Dicerandra has an infundibular corolla, and exerted stamens and style, often declinate along the lower lip (Huck, 1987). In artificial crossing experiments to produce $F 1$ hybrids, annual species were remarkably interfertile when crossed with other annuals and perennials, whereas crosses between perennials were unsuccessful (Huck, 1987). Natural hybrids between annuals are rare, however, and pollen viability counts of individuals in those naturally occurring hybrid swarms was near 90\% (Huck, 1987). Myxocarpy, a situation in which hydrophilic cells, known as slime cells, cover the pericarp wall, characterizes Dicerandra (Huck, 1987) as well as the other taxa of subfamily Nepetoideae (Cantino \& Sanders, 1986). Annual species are located on xeric ridges or on sandy, disturbed areas, usually beside functioning water-courses, in Georgia, Alabama, South Carolina and northern Florida; perennial species are found on isolated dune refugia in central Florida below $29^{\circ} \mathrm{N}$ latitude (Fig. 1). Habitat disturbance is a factor in the ecology of the genus.

\section{MATERIAL AND METHODS}

Buds for chromosome counts were collected in autumn 1994 throughout the range of the genus by the two authors. Pre-flowering buds were fixed in the field in 6 chloroform: 3 ethanol 95\%: 1 glacial acetic acid for 48 hours, rinsed in 70\% ethanol, and then transferred to $70 \%$ ethanol for storage in a freezer. A random collection of 25-30 buds was made from approximately 25 plants at each population site, except for $D$. thinicola, where each bud collection represents a single plant. Plants of this latter species were found in a large population with much variation in flowering time and flower colour. The buds were stained in Snow's alcoholic-hydrochloric acid-carmine (Snow, 1963) for $4-7$ days at $50-60^{\circ} \mathrm{C}$. Single flowers were placed on a slide in a drop of $45 \%$ acetic acid and the calyx was removed. A drop of Hoyer's mounting medium was mixed with the acetic acid and the anthers were excised, cut in half, and spaced before the coverslip was placed. The slide was heated on a warming tray $\left(63^{\circ} \mathrm{C}\right)$ for approximately 3-4 minutes and the coverslip was then pressed to spread the pollen mother cells. When cells with countable chromosomes were observed, they were sketched and, when suitable, camera lucida drawings were made. Slides are quite permanent and will be available for reference as this chromosome study continues. One count is reported for each taxon, except for two counts for $D$. frutescens and $D$. odoratissima from buds from different populations, and three counts from $D$. thinicola from buds from different plants collected in the same population. Voucher specimens have been deposited at FLAS.

\section{RESULTS}

Fifteen chromosome counts for 11 taxa of Dicerandra are reported (Table 1) and representative cells are illustrated in camera lucida drawings (Figs 2-12). Of the 
TA B LE 1. Chromosome numbers ( $n$ ), B chromosome numbers (B), ploidy levels, collection data, ranges and figure numbers for taxa of Dicerandra (Labiatae). [Fig. is numbered camera lucida drawing. ( $\mathrm{T}$ ) is type locality.]

\begin{tabular}{|c|c|c|c|c|c|c|}
\hline Taxa & $n$ & B & Ploidy & Collection data & Range & Fig. \\
\hline \multicolumn{7}{|l|}{ Section Dicerandra } \\
\hline \multicolumn{7}{|l|}{ Dicerandra linearifolia } \\
\hline var. linearifolia & 24 & +1 & $6 x$ & $\begin{array}{l}\text { FL: Washington Co.; } \\
\text { Huck } 5149 \text { with } \\
\text { Chambers, } 19 \text { ix } \\
1994\end{array}$ & $\mathrm{AL}, \mathrm{GA}, \mathrm{N}$ FL & 2 \\
\hline var. robustior & 16 & & $4 x$ & $\begin{array}{l}\text { FL: Liberty Co.; } \\
\text { Huck } 5150 \text { with } \\
\text { Chambers, } 19 \text { ix } \\
1994\end{array}$ & $\begin{array}{l}\text { W of } \\
\text { Suwannee } \\
\text { River, N FL }\end{array}$ & 3 \\
\hline D. densiflora & 24 & $+1-2$ & $6 x$ & $\begin{array}{l}\text { FL: Lafayette Co.; } \\
\text { Huck 5189, } 25 \text { x } \\
1994\end{array}$ & $\begin{array}{l}\text { E of Suwannee } \\
\text { River, N FL }\end{array}$ & 4 \\
\hline \multirow[t]{2}{*}{ D. frutescens } & 24 & & $6 x$ & $\begin{array}{l}\text { FL: Highlands Co.; } \\
\text { Huck 5138, } 10 \text { ix } \\
1994\end{array}$ & $\begin{array}{l}\text { W side of Lake } \\
\text { Wales Ridge, } \\
\text { C FL }\end{array}$ & \\
\hline & 24 & $+1-2$ & & $\begin{array}{l}\text { FL: Highlands Co.; } \\
\text { Huck 5139, } 10 \text { ix } \\
1994\end{array}$ & & 5 \\
\hline D. immaculata & 24 & +1 & $6 x$ & $\begin{array}{l}\text { FL: St Lucie Co.; } \\
\text { Huck } 5141 \text { with } \\
\text { Chambers, } 17 \text { ix } \\
1994\end{array}$ & $\begin{array}{l}\text { Atlantic } \\
\text { Coastal Ridge, } \\
\text { S-C FL }\end{array}$ & 6 \\
\hline D. cornutissima & 16 & +1 & $4 x$ & $\begin{array}{l}\text { FL: Marion Co.; } \\
\text { Huck } 2436, \text { voucher } \\
\text { (T); buds collected } \\
20 \text { ix } 1994\end{array}$ & $\begin{array}{l}\text { Central ridge, } \\
\text { N-C FL }\end{array}$ & 7 \\
\hline D. christmanii & 16 & & $4 x$ & $\begin{array}{l}\text { FL: Highlands Co.; } \\
\text { Huck } 5144 \text { with } \\
\text { Chambers, } 17 \text { ix } \\
1994\end{array}$ & $\begin{array}{l}\text { E side of Lake } \\
\text { Wales Ridge, } \\
\text { C FL }\end{array}$ & 8 \\
\hline \multirow[t]{3}{*}{ D. thinicola } & 16 & & $4 x$ & $\begin{array}{l}\text { FL: Brevard Co.; } \\
\text { Huck } 5161 \text { with } \\
\text { Chambers, } 22 \text { ix } \\
1994\end{array}$ & $\begin{array}{l}\text { Atlantic } \\
\text { Coastal Ridge, } \\
\text { N-C FL }\end{array}$ & 9 \\
\hline & 16 & & & $\begin{array}{l}\text { FL: Brevard Co.; } \\
\text { Huck } 5151 \text { with } \\
\text { Chambers, } 22 \text { ix } \\
1994\end{array}$ & & \\
\hline & 16 & & & $\begin{array}{l}\text { FL: Brevard Co.; } \\
\text { Huck } 5166 \text { with } \\
\text { Chambers, } 22 \text { ix } \\
1994 \text { (T) }\end{array}$ & & \\
\hline D. frutescens subsp. nov. & 16 & & $4 x$ & $\begin{array}{l}\text { FL: Polk Co.; Huck } \\
5143 \text { with Chambers, } \\
17 \text { ix } 1994\end{array}$ & $\begin{array}{l}\text { E side of Lake } \\
\text { Wales Ridge, } \\
\text { C FL }\end{array}$ & 10 \\
\hline
\end{tabular}


Section Lecontea

D. odoratissima

$16+1-24 x$

GA: Coffee Co.;

SC, GA

Huck 5132, 2 ix 1994

(T)

16

GA: Tattnall Co.;

11

Huck 5135, 3 ix 1994

D. radfordiana

16

$4 x$

GA: McIntosh Co.;

S-E GA

12

Huck 2181, voucher

( $\mathrm{T})$; buds collected 3

ix 1994

eleven taxa studied seven have $n=16$ and four have $n=24$ (Table 1 ). These numbers suggest $x=8$. However, if this is the case, there are no known diploid species and the chromosome levels represented by the above are tetraploid and hexaploid respectively (Table 1). A base chromosome number of 8 is not unusual in the Labiatae. Other genera in the subfamily Nepetoideae with chromosomes that suggest this base number are Elsholtzia Willd. and Salvia L. (Goldblatt \& Johnson, 1994), Satureja L. and Melissa L. (Federov, 1969) and Monarda L. (Irving, 1976). Ranging from 1-4, B chromosomes were observed in most taxa (Table 1; Figs 2-12), including 2-4 in D. thinicola; they were visible at diakinesis but not at later stages, and thus they may occur in other cells.

\section{DISCUSSION}

The phytogeographic pattern of Dicerandra with hexaploid taxa sympatric or parapatric with tetraploids, missing diploids and isolated populations of perennial species coincident with major ridge systems in Florida (Fig. 1) implies a complicated evolutionary history for this genus. The successive fall and rise of sea level during the Pleistocene (Cooke, 1939; Neill, 1957; White, 1970) presumably opened up disturbed habitats for colonizing genera such as Dicerandra. The buoyant mucilaginous fruit (myxocarpy) of this genus was perhaps an important factor in the movement of propagules along ancient waterways in the south-eastern United States. Deposition and isolation on dune 'islands' presumably set the stage for genetic divergence and speciation. Isolated North American genera such as Conradina A. Gray, Stachydeoma Small, Acanthomintha A. Gray, Monardella Benth. and Pogogyne Benth., as well as other isolated genera discussed by Hedge (1992), are common in the Labiatae. Extinct diploids of Dicerandra probably occupied habitats no longer present today, such as those habitats discussed by Watts (1983). Missing diploids in genera such as Hyptis (Harley \& Heywood, 1992) are also well known in the Labiatae.

Polyploidy can be viewed as a stabilizing force in the evolution of taxa in Dicerandra. Tetraploids $(n=16)$ in Dicerandra are presumed to be allopolyploids, formed by a doubling of base chromosome number $(n=8)$ after hybridization events (see Stebbins, 1971; De Wet, 1975). Dicerandra may be an example of secondary 


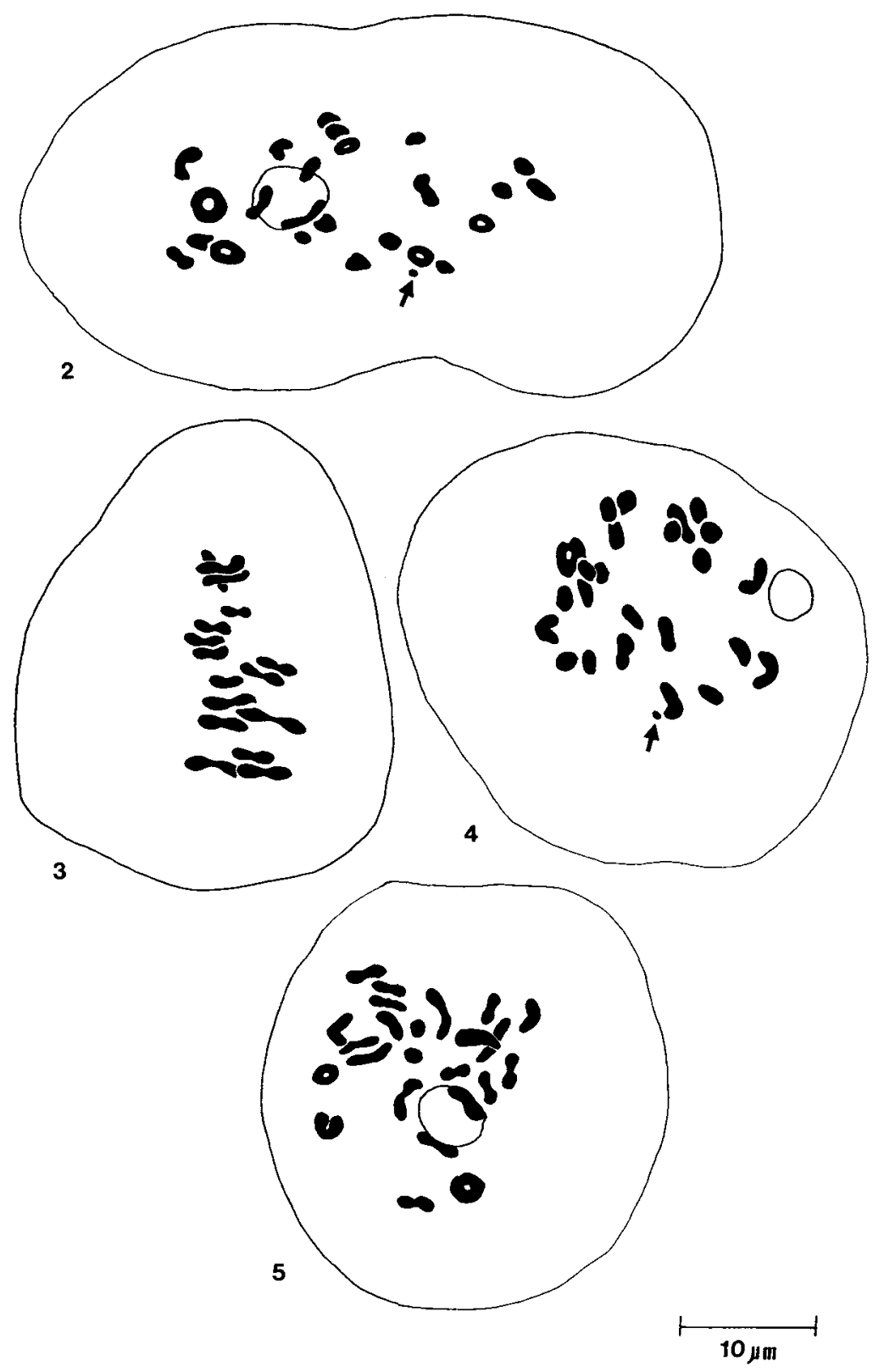

FIGS 2-5. Camera lucida drawings of pollen mother cell meiosis in Dicerandra: FIG. 2. D. linearifolia var. linearifolia, Diakinesis, $n=24$ plus B chromosome (arrow) (5149). FIG. 3. D. linearifolia var. robustior, Metaphase I, $n=16$ (5150). FIG. 4. $D$. densiflora, Diakinesis, $n=$ 24 plus B chromosome (arrow). FIG. 5. D. frutescens, Diakinesis, $n=24$ (5139); note that the two round 'blobs' to the left and above the nucleolus are each bivalents. 


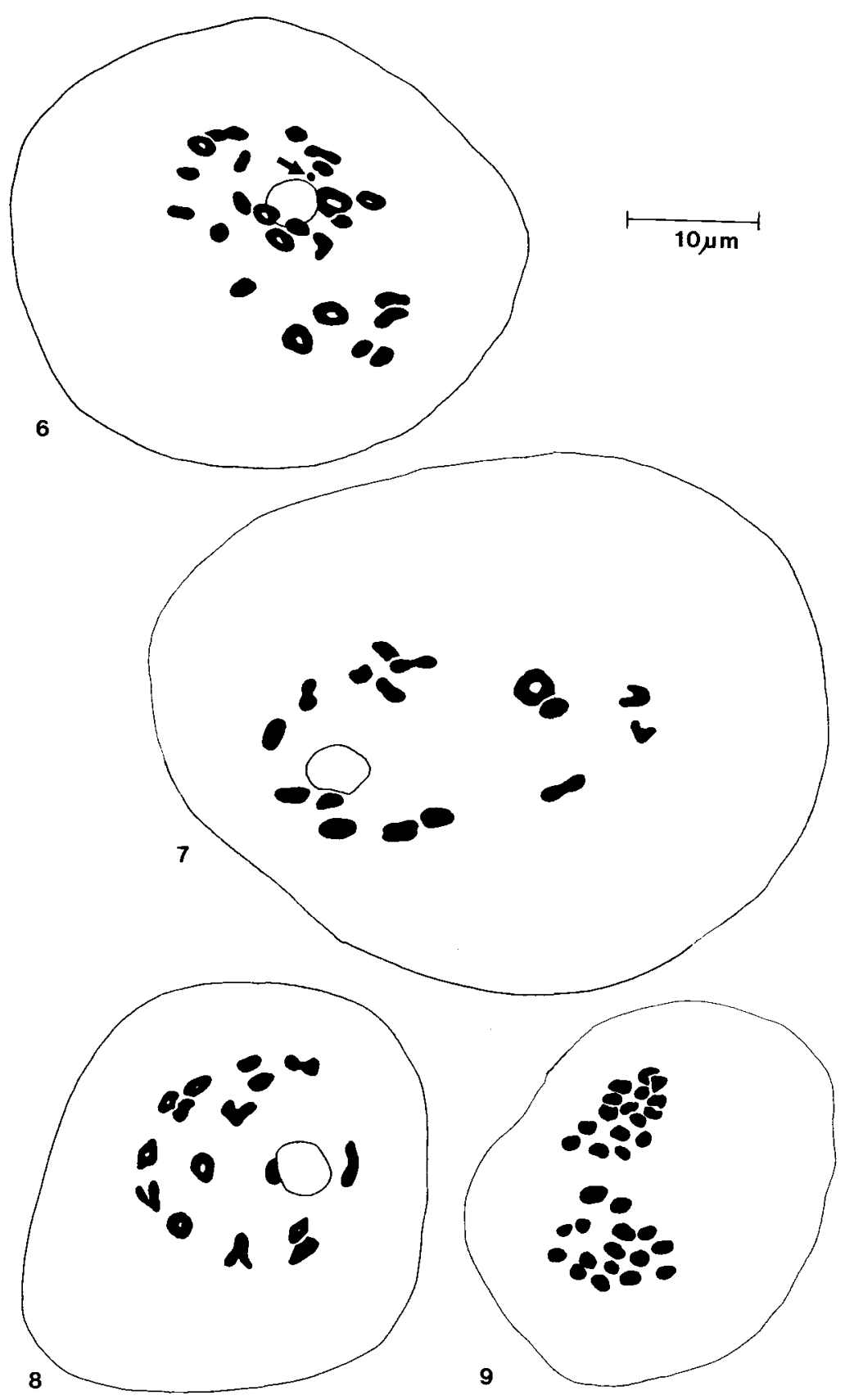

FIGS 6-9. Camera lucida drawings of pollen mother cell meiosis in Dicerandra: FIG. 6. D. immaculata, Diakinesis, $n=24$ plus B chromosome (arrow) (5141). FIG. 7. D. cornutissima, Diakinesis, $n=16$ (2436). FIG. 8. D. christmanii, Diakinesis, $n=16$ (5144). FIG. 9. D. thinicola, Metaphase II, $n=16$ (5161). 


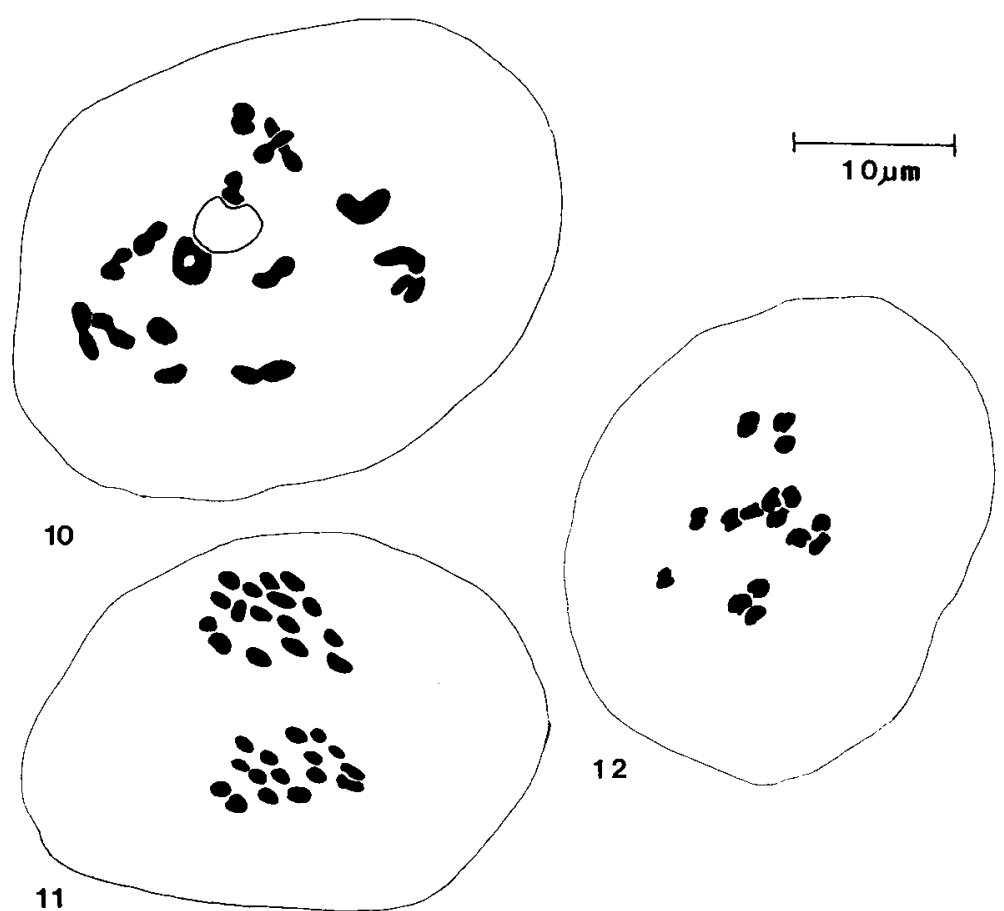

FIGS 10-12. Camera lucida drawings of pollen mother cell meiosis in Dicerandra: FIG. 10. D. frutescens subsp. nov., Diakinesis, $n=16$ (5143). FIG. 11. D. odoratissima, Metaphase II, $n=16$ (5135). FIG. 12. D. radfordiana, Prometaphase I (very much contracted late diakinesis), $n=16(2181)$.

hybrid polyploidy discussed by Stebbins (1971), in which hybrid tetraploids $(n=16)$ backcross to ancestral diploids $(n=8)$. Such a hypothetical cross in Dicerandra would yield triploid hybrids $(n=12)$, which, if doubled, could produce hexaploids $(n=24)$ with good chromosomal pairing and normal meiosis. Presence of B chromosomes in a majority of Dicerandra species is consistent with their known occurrence in the Labiatae (Jones, 1995). Although their significance is not completely understood, B chromosomes may imply continuing evolution in the genus as suggested by Harley and Heywood (1992) for subgenus Calophace in Salvia.

Our cytological study aids in understanding relationships in the genus and highlights some taxa for review and discussion. Previously, Kral (1982) has suggested that the section now delineated as sect. Lecontea is so different from sect. Dicerandra that it could be treated as a new genus. However, chromosome numbers of $n=16$ and a presumed base number of $x=8$ are found in both sections of Dicerandra (Table 1). Continued inclusion, at least for the time being, of sect. Lecontea within the genus Dicerandra is supported by these studies.

Dicerandra odoratissima Harper and D. radfordiana Huck, both annuals with chromosome counts of $n=16$ in sect. Lecontea, are found in a small area of Georgia and 
South Carolina (Fig. 1; Table 1). Although it was hypothesized that D. radfordiana might have a higher chromosome number since its corolla dimensions, fruit diameter and pollen size are approximately twice the size of D. odoratissima (Huck, 1987), this is not the case. Discontinuities in flavonoid profiles between the two species have been found (Huck, unpublished data). Barely 100 plants of $D$. radfordiana remain in the wild.

Dicerandra linearifolia (Ell.) Benth. var. linearifolia, an annual with pale pink to white corollas, yellow anthers and narrow leaves, is found in northern Georgia and north-west Florida (Fig. 1). Chromosome counts of the type variety are $n=24$, a hexaploid (Table 1). The type for the species and for the genus as collected by Elliott in 1821 presumably, then, was a hexaploid. The variety $D$. linearifolia (Ell.) Benth. var. robustior Huck, with dark purple corollas, reddish brown anthers and wider leaves found in northern Florida, is a tetraploid, with counts of $n=16$ (Table 1; Fig. 1). Differences in morphology of floral features, geography and, now, chromosome number, suggest that these two varieties may be better addressed as subspecies of Dicerandra linearifolia. Further chromosome counts of this species throughout its range are needed.

The distinctive Dicerandra densiflora Benth., with small lavender corollas, a short tube and anthers with brush-like spurs, is a hexaploid ( $n=24$; Table 1). This annual is found in the Suwannee River Basin between northern annuals and southern perennial taxa of the genus (Fig. 1).

In 1962 L.H. Shinners described the first perennial in the genus, Dicerandra frutescens Shinners. Distribution of this species as recognized by Shinners was from north to south along the central ridges in Florida and terminated at the Lake Wales Ridge (sensu White, 1970), a distance of some 180 miles $(257 \mathrm{~km})$. As it is now circumscribed, $D$. frutescens occurs only on the western flank of the Lake Wales Ridge (Fig. 1). This species is a hexaploid ( $n=24$; Table 1), has a white corolla with purple marks on the standard, flavonoids that vibrantly fluoresce under UV light (Huck, unpublished data) and a unique antifeedant chemical (Eisner et al., 1990).

Since 1962 two other Dicerandra species, both tetraploids $(n=16)$, have been discovered within the original range for Dicerandra frutescens as delineated by Shinners (Table 1; Fig. 1). In 1981 Dicerandra cornutissima Huck occurring in north central Florida was recognized. This species has a mat of basal leaves, reddish purple corollas and long, slender spurs on the white anthers. In 1989, yet another species was recognized, Dicerandra christmanii Huck \& Judd, with an oil profile of 1,8-cineole and $\alpha$-terpineol unlike the pulegone found in other perennial Dicerandra species (Huck et al., 1989). This latter species with pale yellow anthers and dangling corollas was found only 7 miles $(11.2 \mathrm{~km})$ from $D$. frutescens. Now it appears that there is yet another undescribed taxon, an apparent new subspecies of $D$. frutescens, on the eastern flank of the Lake Wales Ridge, a tetraploid, at $n=16$ (Fig. 1; Table 1). This latter taxon resembles hexaploid $D$. frutescens, and the corolla undergoes two colour phases: yellow, in anther-dehiscent stage, and white fading to dark pink, in the stigma-receptive stage. The spurs are longer than $D$. frutescens, and the taxon has somewhat wider leaves. Further research is needed to clarify this undescribed taxon. 
The Atlantic Coastal Ridge in Florida, another site of great endemism (Austin et al., 1987), runs parallel to the species-rich Lake Wales Ridge (Fig. 1), but is of more recent origin than the interior ridge (Tanner, 1992). On the southern part of the Atlantic Coastal Ridge Dicerandra immaculata Lakela, a hexaploid, with $n=24$ (Fig. 1; Table 1) is found. This species has a pale pink corolla, an immaculate standard and intensely hairy spurs on the anthers. Dicerandra thinicola H.A. Miller, a recently named species just to the north on the same ridge, is a tetraploid, with $n=16$ (Table 1). This latter species can be distinguished by a wide corolla throat in which the palate holding the stigma is clearly visible during anthesis. Considerable variability in floral colour, and an autumn blooming period concurrent with northern species, are apparent. Some pollen inviability and corolla shape differences characterize this species, but chromosome numbers are constant (Table 1).

Addition of new character information on chromosome numbers requires a refinement of earlier phylogenetic analyses presented by Huck (1987) and Huck and co-workers (1989) for Dicerandra. The monophyletic nature of the genus which includes sect. Dicerandra and sect. Lecontea as proposed in those analyses is upheld by the discovery that the base number for both sections is presumably $x=8$. The hypothetical ancestors of these two clades are possibly the missing diploids. Hexaploidy has evolved independently in both perennial and annual groups in all four branches of sect. Dicerandra but not in sect. Lecontea. Since polyploid differences in hexaploids and tetraploids may be used to imply relative ages of the taxa (Kruckeberg \& Rabinowitz, 1985), possible speculative relationships may be suggested in Dicerandra: hexaploid $D$. linearifolia var. linearifolia younger than tetraploid $D$. linearifolia var. robustior and hexaploid $D$. frutescens in Highlands County in Florida younger than a new tetraploid subspecies in Polk County (Fig. 1; Table 1). The Lake Wales Ridge group including $D$. frutescens, $D$. christmanii and a suspected new subspecies (or species, pending results of further research) of $D$. frutescens appears to form an evolutionary unit; populations with their respective ploidy levels should be represented in conservation programmes.

A speculative phytogeographic scenario for the genus might include an origin of the diploid Dicerandra in the Appalachian Province, with movement into the Coastal Plain, as has occurred with other species (Thorne, 1993). A re-radiation of taxa from Apalachicola refugia to the north and south in the late Pleistocene is possible. This general pattern might have included the early separation of the annuals and perennials in sect. Dicerandra with hexaploid $D$. densiflora more recently evolved and occupying the ancient area known by biogeographers such as Webb (1990) as the Suwannee Strait in Florida. In areas of sympatry, possibly of recent origin, rare hybrids occur between annuals hexaploid $D$. densiflora and tetraploid $D$. linearifolia var. robustior and between hexaploid $D$. linearifolia var. linearifolia and tetraploid $D$. odoratissima (Fig. 1). An early radiation centre is now apparent in the Lake Wales Ridge.

\section{CONCLUSIONS}

The pattern of missing diploids and extant hexaploids and tetraploids with many isolated endemics suggests that Dicerandra is an old polyploid complex. Our 
interpretation of the cytological data further implies that development of tetraploids and hexaploids occurred when diploids were present early in the history of Dicerandra, possibly in response to a radically changing environment. While polyploidy certainly plays a role in isolation of species, it is seen as a stabilizing factor following hybridization, an apparent theme in outcrossing Dicerandra. Further, the tremendous variability carried in polyploid taxa masks the expression of recessive alleles (Briggs \& Walters, 1984) and serves as a genetic reservoir for the continuing vitality of small populations in genera such as Dicerandra. Further research will include a chromosome count survey of the widespread $D$. linearifolia, as well as counts of any newly discovered populations of Dicerandra.

\section{ACKNOWLEDGEMENTS}

Dr Kim E. Hummer, Research Leader and Curator, is thanked for the use of the facilities at the National Clonal Germplasm Repository (USDA-ARS), Corvallis. We thank William A. Stern, University of Florida, for loaning material and chemicals for use in the collection of chromosome material. Nancy J. Bissett and Kris DeLaney are thanked for showing us populations of their discovery of a new Dicerandra. We await their description and naming of this taxon so that it can be included in the Flora of North America. We thank Robert L. Dressler, University of Florida, and C. Ritchie Bell, Emeritus Professor at the University of North Carolina, Chapel Hill, and Anne $\mathrm{H}$. Lindsey for critical comments on the manuscript. We express our gratitude to Kent Perkins, Collections Manager, and Norris H. Williams, Keeper of the Herbarium, University of Florida, for their continuing generosity and support. Leave time and other support was given by the Florida Department of Environmental Protection. We thank the referees of the Edinburgh Journal of Botany for insightful remarks.

\section{REFERENCES}

AUSTIN, D. F., POSIN, F. R. \& BURCH, J. N. (1987). Scrub species patterns on the Atlantic Coastal Ridge, Florida. J. Coastal Research 3: 491-498.

Bent HAM, G. (1848). Labiatae. In: DE CANDOLlE, A. (ed.) Prodromus Systematis Naturalis Regni Vegetabilis 12: 27-603. Paris: Victoria Masson.

BENTHAM, G. \& HOOKER, J. D. (1876). Genera Plantarum, Vol. II. London: Williams and Norgate.

BRIGGS, D. \& WALTERS, S. M. (1984). Plant Variation and Evolution. Ed. 2. Cambridge: Cambridge University Press.

CANTINO, P. D. \& SANDERS, R. W. (1986). Subfamilial classification of Labiatae. Syst. Bot. 11: 163-185.

CHAMBERS, H. L. (1961). Chromosome numbers of breeding systems in Pycnanthemum (Labiatae). Brittonia 13: 116-128.

CHAMBERS, H. L. \& CHAMBERS, K. L. (1971). Artificial and natural hybrids in Pycnanthemum (Labiatae). Brittonia 23: 71-88.

CHAMBERS, H. L. \& HUMMER, K. E. (1994). Chromosome counts in the 
Mentha collection at the USDA-ARS National Clonal Germplasm Repository. Taxon 43: 423-432.

CHRISTMAN, S. P. \& JUDD, W. S. (1990). Notes on plants endemic to Florida scrub. Florida Sci. 53: 52-73.

COOKE, C. W. (1939). Scenery of Florida interpreted by a geologist. Geological Bulletin No. 17. Tallahassee: Florida Geological Survey.

DE WET, J. M. J. (1975). On O Winge and a Prayer: the origin of polyploids. Bot. Rev. 41: $361-390$.

EISNER, T., MCCORMICK, K. D., SKAION, M., EISNER, M., SMEDLEY, S. R., ANESHANSLEY, D. J., DEYRUP, M., MYERS, R. L. \& MIENWALD, J. (1990). Chemical defenses of a rare mint plant. Chemoecology 1 : 30-37.

FEDOROV, A. (ed.) (1969). Chromosome numbers of flowering plants. Komarov Botanical Institute: St Petersburg.

GILL, L. S. (1981). Chromosomal evidence and incidence of polyploidy in the Canadian Labiatae. Rev. Cytol. Biol. Veg. Botaniste 4: 331-339.

GOLDBLATT, P. \& JOHNSON, D. E. (eds) (1994). Lamiaceae in Index to Plant Chromosome Numbers 1990-1991. Monographs in Systematic Bot. (Missouri Bot. Garden) 51: 115-121.

GRAY, T. C. (1965). A monograph of the genus Conradina A. Gray (Labiatae). Ph.D. thesis, Vanderbilt University.

HARLEY, R. M. \& BRIGHTON, C. A. (1977). Chromosome numbers in the genus Mentha. Bot. J. Linn. Soc. 74: 71-96.

HARLEY, R. M. \& HEYWOOD, C. A. (1992). Chromosome numbers in Tropical American Labiatae. In: HARLEY, R. M. \& REYNOLDS, T. (eds) Advances in Labiate Science, pp. 211-246. Kew: Royal Botanic Gardens.

HEDGE, I. C. (1992). A global survey of the biogeography of the Labiatae. In: HARLEY, R. M. \& REYNOLDS, T. (eds) Advances in Labiate Science, pp. 7-17. Kew: Royal Botanic Gardens.

HUCK, R. B. (1987). Dicerandra. Phanerogamarum Monographiae 19. Berlin-Stuttgart: J. Cramer.

HUCK, R. B. (1992). Overview of pollination biology in the Lamiaceae. In: HARLEY, R. M. \& REYNOLDS, T. (eds) Advances in Labiate Science, pp. 167-181. Kew: Royal Botanic Gardens.

HUCK, R. B., JUDD, W. S., WhITTEN, W. M., SKEAN, J. D. JR., WUNDER LIN, R. P. \& DELANEY, K. R. (1989). A new Dicerandra (Labiatae) from the Lake Wales Ridge of Florida with cladistic analysis and discussion of endemism. Syst. Bot. 14: 197-213.

IRVING, R. S. (1976). Chromosome numbers in Hedeoma (Labiatae) and related genera. Syst. Bot. 1: 46-56.

JONES, R. N. (1995). Tansley Review No. 85. B chromosomes in plants. New Phytol. 131: 411-434.

KRAL, R. (1982). Some notes on Dicerandra (Lamiaceae). Sida 9: 238-262.

KRUCKEBERG, A. R. \& RABINOWITZ, D. (1985). Biological aspects of endemism in higher plants. Ann. Rev. Ecol. Syst. 16: 447-479.

LEWIS, P. O. \& CRAWFORD, D. J. (1995). Pleistocene refugium endemics exhibit greater allozyme diversity than widespread congeners in the genus Polygonella (Polygonaceae). Amer. J. Bot. 82: 141-149.

MARRERO, A. (1992). Chromosomal evolutionary trends in the genus Sideritis subgenus marrubiastrum. In: HARLEY, R. M. \& REYNOLDS, T. (eds) Advances in Labiate Science, pp. 247-256. Kew: Royal Botanic Gardens. 
MCCORMICK, K. D., DEYRUP, M. A., MENGES, E. S., WALLACE, S. R., MEINWALD, J. \& EISNER, T. (1993). Relevance of chemistry to conservation of isolated populations: The case of volatile leaf components of Dicerandra mints. Proc. Natl. Acad. Sci. USA 90: 7701-7705.

MCDONALD, D. B. \& HAMRICK, J. L. (1996). Genetic variation in some plants of Florida Scrub. Amer. J. Bot. 83: 21-27.

NEILL, W. T. (1957). Historical biogeography of present-day Florida. Bull. Fla. State Mus. 2: 175-221.

SNOW, R. (1963). Alcoholic hydrochloric acid-carmine as a stain for chromosomes in squash preparations. Stain Tech. 28: 9-13.

STEBBINS, G. L. (1971). Chromosomal Evolution in Higher Plants. London: AddisonWesley.

TANNER, W. F. (1992). Natural environment. In: FERNALD, E. A. \& PURDUM, E. D. (eds) Atlas of Florida, pp. 12-77. Gainesville: University Presses of Florida.

THORNE, R. F. (1993). Phytogeography. In: FLORA OF NORTH AMERICA EDITORIAL COMMITTEE (eds) Flora of North America Vol. 1, pp. 132-153. New York: Oxford University Press.

WATTS, W. A. (1983). Vegetation history of the Eastern United States 25,000 to 10,000 years ago. In: PORTER, S. C. (ed.) Late-Quaternary Environments of the United States, The Late Pleistocene, Vol. 1, pp. 294-310. Minneapolis: University of Minnesota Press.

WEBB, S. D. (1990). Historical biogeography. In: MYERS, R. L. \& EWEL, J. J. (eds) Ecosystems of Florida, pp. 70-100. Orlando: University of Central Florida Press.

WHITE, W. A. (1970). Geomorphology of the Florida Peninsula. Geological Bulletin No. 51. Tallahassee: Florida Bureau of Geology, Depart. Nat. Res.

Received 12 February 1996; accepted with minor revision 10 October 1996 